\section{STUDENTS' UNDERSTANDING OF AXIAL AND CENTRAL SYMMETRY}

\begin{abstract}
The paper focuses on students' understanding of the concepts of axial and central symmetries in a plane. Attention is paid to whether students of various ages identify a non-model of an axially symmetrical figure, know that a line segment has two axes of symmetry and a circle has an infinite number of symmetry axes, and are able to construct an image of a given figure in central symmetry. The results presented here were obtained by a quantitative analysis of tests given to nearly 1,500 Czech students, including pre-service mathematics teachers. The paper presents the statistics of the students' answers, discusses the students' thought processes and presents some of the students' original solutions. The data obtained are also analysed with regard to gender differences and to the type of school that students attend. The results show that students have two principal misconceptions: that a rhomboid is an axially symmetrical figure and that a line segment has just one axis of symmetry. Moreover, many of the tested students confused axial and central symmetry. Finally, the possible causes of these errors are considered and recommendations for preventing these errors are given.
\end{abstract}

\section{KEYWORDS}

Axial symmetry, central symmetry, circle, geometrical concepts, line segment, rhomboid

\section{HOW TO CITE}

Moravcová V., Robová J., Hromadová J., Halas Z. (2021) 'Students' Understanding of Axial and Central Symmetry', Journal on Efficiency and Responsibility in Education and Science, vol. 14, no. 1, pp. 28-40. http://dx.doi.org/10.7160/eriesj.2021.140103

\section{Vlasta Moravcová \\ Jarmila Robová \\ Jana Hromadová \\ Zdeněk Halas}

Department of Mathematics

Education, Faculty of Mathematics

and Physics, Charles University, Czech

Republic

Vlasta.Moravcova@mff.cuni.cz

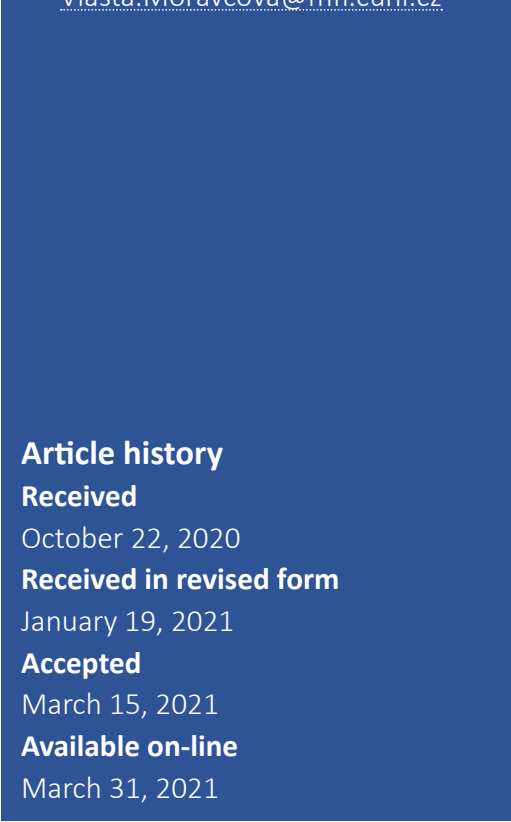

\title{
Highlights
}

- Students are persuaded a rhomboid is an axially symmetrical figure.

- Students believe a line segment has just one axis of symmetry.

- Students prefer a vertical axis of symmetry.

- Czech mathematics textbooks do not contain a sufficient number of non-models of symmetrical figures.

\section{INTRODUCTION}

Geometry is an important area of school mathematics that can be difficult for students. ${ }^{1}$ Some current critical points of teaching geometry in the Czech Republic have been described by Rendl and Vondrová (2013). Similar problems also occur in other countries (Adolphus, 2011; Mirna, 2018; Geçici and Aydın, 2020). Some of the problems in the current teaching geometry are related to a number of changes that have taken place in the past in our country. The teaching of mathematics changed as a result of the school mathematics modernization between 1965 and 1985 (Tichá, 2013). Jirotková (2017: 154) pointed out that 'the conception of teaching geometry at all levels changed from geometry of speculation to axiomatic structure geometry' in this period and that it caused that 'pupils' ideas of [basic] concepts were often deformed as they were not anchored in the pupil's experience.' In our teaching experience, we also encounter the problematic understanding of basic geometrical concepts in students. Therefore, we have focused on this issue more in-depth.

The analysis of students' understanding of geometrical concepts can be supported by several cognitive theories, the most well-known of which is probably van Hiele's Theory (van Hiele, 1986; Mayberry, 1983). This theory describes the five thought levels of student thinking in geometry, which are commonly called: visualization, analysis, abstraction, deduction and rigor. Tall et al (2001) look at teaching geometry from the perception of shapes through the manipulation of prototypes of objects to the proof and axiomatic construction of geometry. According to the Theory of Generic Models (Hejný, 2012), students gain abstract knowledge from isolated models through generic 1 In Czech legislation, the terms pupil and student are distinguished according to age and are not interchangeable. However, for simplicity, we use the term student for all age groups in this paper. 
models and the whole cognitive process begins with motivation. Hejný (2000) also deals with the term procept in geometry, in which two cognitive principles - process and concept - are connected. This term, as an expression for a type of high-quality knowledge, was introduced by Gray and Tall (1994), but they did not use it in connection with geometry. The terms process and concept are related to procedural and conceptual knowledge, which are two key cognitive principles in mathematics education. The first one means an action sequence needed for solving mathematical problems, the second one can be defined as an understanding of the fundamental principles and connections of a particular mathematical domain (Hiebert and Lefevre, 1986; Star, 2005). According to many researchers, these two types of knowledge interact (e.g., Rittle-Johnson and Alibali, 1999; Rittle-Johnson, Siegler and Alibali, 2001; Rittle-Johnson and Schneider, 2015; Vondrová et al, 2015).

As part of our long-term pedagogical research, ${ }^{2}$ we deal with students' problems with geometry to improve the training of pre-service mathematics teachers for lower and upper secondary schools. We primarily focused on students' understanding of selected geometrical concepts. We have already examined students' concepts of a triangle (Robová et al, 2019), a trapezoid (Halas et al, 2019), a straight line (Moravcová and Hromadová, 2020) and the rotation of a straight line (Halas et al, 2020). In this paper, we focus on axial and central symmetry in a plane, thus loosely following the contribution (Moravcová et al, 2019) devoted only to axial symmetry and presented during the ERIE conference 2019.

Axial and central symmetry are special types of isometries. Axial symmetry in a plane given by a straight line (the axis of symmetry) is also called reflection/mirror symmetry/ line symmetry, etc. Central symmetry in a plane (also point symmetry, point reflection, etc.) is a special case of rotation in a plane by $180^{\circ}$ around a centre point. ${ }^{3}$ It can also be composed of two axial symmetries with orthogonal axes. Czech students first become acquainted with axial symmetry in primary school. According to the national curriculum (Ministry of Education, Youth and Sports, 2017: 33 ), a student at the end of the 5th grade is able to 'recognize and draw a simple axially symmetrical figure on a square mesh and determine the axis of symmetry by folding a paper in its place'. By the end of the 9th grade (lower secondary school), a student is able to 'draft and construct a plane shape in a point symmetry and to determine an axially symmetrical shape' (Ministry of Education, Youth and Sports, 2017: 36). Translation and general rotation are taught at upper secondary school (Ministry of Education, Youth and Sports, 2007). These curricular requirements are usually reflected in the contemporary Czech mathematics textbooks. In the Czech Republic, all these isometries are taught with emphasis on their geometric meaning and visualization.

2 The research team consists of members of the Department of Mathematics Education, Faculty of Mathematics and Physics, Charles University, who are the authors of this paper.

3 More precisely, by $180^{\circ}+k \cdot 360^{\circ}$, where $k$ is an integer.
Many researches of the students' and pre-service teachers' knowledge have focused the isometries. Some of them have dealt with the comparison of all isometries. The results suggest that rotation is the most difficult of them; axial symmetry is the easiest (Ada and Kurtuluş, 2010; Hollebrands, 2004; Xistouri and Pitta-Pantazi, 2011). Several studies have highlighted frequent misconceptions such as: confusing axial and central symmetries (Son, 2006; Jagoda, 2008); problems with constructing a mirror image in axial symmetry with an oblique axis of symmetry (Jagoda, 2008); problems with finding the axis of symmetry correctly (Hacısalihoğlu-Karadeniz et al, 2015; Kaplan and Öztürk, 2014); and incorrect identification of a figure that is not axially symmetrical as an axially symmetrical one, e.g., a rhomboid (Son, 2006; Aktaş and Ünlü, 2017; Hacısalihoğlu-Karadeniz et al, 2015; Leikin, Berman and Zaslavsky, 2000). Aktaş and Ünlü (2017), Herendiné-Kónya (2008) and Hollebrands (2004) pointed out the problems that students of different ages have with constructing a simple planar figure in central symmetry. According to several research studies (e.g., Fryer and Levitt, 2010; Wang and Degol, 2017), males tend to be more successful in mathematics, especially in geometry. However, Kambilombilo and Sakala (2015) dealt with gender differences in the area of isometries and found out that there were no significant differences between males and females.

Some researchers have pointed out that students can achieve a better understanding of isometries with support of the education process by appropriate software, especially dynamic geometry computer programs (e.g., Ada and Kurtuluş, 2010; Köse and Özdaş, 2009; Hollebrands, 2004; Lobato and Ellis, 2002). The chosen procedural methods in teaching also have a significant influence on the quality of teaching (Jagoda, 2008; Herendiné-Kónya, 2008). Therefore, paying attention to the quality of the training of pre-service teachers is also important. Many studies have shown that pre-service teachers focus mainly on procedural knowledge and are not able to develop students' conceptual knowledge; moreover, they themselves do not have sufficient conceptual knowledge. In the training of pre-service teachers, emphasis should also be placed on conceptual knowledge (Shulman, 1986; Hacısalihoğlu-Karadeniz, Kaya and Bozkuş, 2017; Son, 2006; Thaqi, Giménez and Rosich, 2011).

In our pedagogical practice, we also encounter the above-mentioned problems (confusing axial and central symmetries, problems with the finding of all axes of an axially symmetrical figure, identification of an axially asymmetrical figure, etc.). Therefore, we focused, among other things, on monitoring these phenomena in our largescale testing. Specifically, we were interested in three problems concerning axial symmetry and one problem concerning central symmetry:

- Do students recognize that a rhomboid is not an axially symmetrical figure?

- Are students able to find all symmetry axes of a line segment? 
- Do students know that the number of symmetry axes of a circle is infinite?

- Are students able to construct an image of a given figure in central symmetry?

According to mentioned research studies and our pedagogical practice, given topics are problematic for school mathematics and students do mistakes in these fields. We have also dealt with the achievement of students from different types of schools, the success of pre-service teachers and gender differences.

First, the paper presents the methodology of our testing. In the Results section, the statistical analysis of testing results is presented and the most important findings are pointed out. These findings are subsequently discussed in detail in the Discussion section. This section also introduces other interesting students' solutions and considers the possible causes of frequent errors. Last but not least, our conclusions are compared with other previous research. The Conclusion section briefly summarizes the most important results, answers the questions asked from the point of view of our research, suggests some recommendations for teaching mathematics and outlines the direction of our further research in this area.

\section{MATERIALS AND METHODS}

Our long-term empirical research into students' understanding of geometrical concepts combines quantitative (didactic testing of a large sample of respondents and statistical data processing) and qualitative methods (use of semi-structured interviews and in-depth analysis of students' opinions and errors).
In the first phase, we prepared three didactic tests for students of different ages: Test I for ISCED I graduates, Test II for ISCED II graduates, and Test III for ISCED III graduates and university students. The test tasks were focused on concepts from the field of planar geometry with emphasis on the concepts that students typically struggle with, according to our teaching experience. The tests were designed so that it was possible to monitor how students of all ages cope with the same or similar task (i.e., Test II is an extension of Test I and Test III is an extension of Test II). Formulations of the test tasks were based on commonly used textbooks and complied with the Czech national curriculum (Ministry of Education, Youth and Sports, 2007, 2017).

The clarity of the tasks and the time limit for solving each of three tests were first verified in the form of pre-tests with small groups of respondents. In addition, researchers conducted semi-structured interviews with several randomly selected students about their solutions in order to verify whether and how the students understand the questions, how they think about the solutions, whether they consider other answers to closed questions than those offered, etc. The original tests were then modified based on these pre-tests.

In this paper, we deal with axial and central symmetries in a plane. These symmetries were monitored in two test tasks which did not need to be modified after the pre-tests. One task in each of the tests was devoted to axial symmetry. We asked students to determine the number of symmetry axes of the three figures shown. The given figures were an isosceles triangle in Test I, a circle in Tests II and III, and a rhomboid and a line segment in all the tests (Figures 1 and 2). All the figures were placed in a square grid. In addition to indicating the number of axes, students could also draw axes in the pictures.

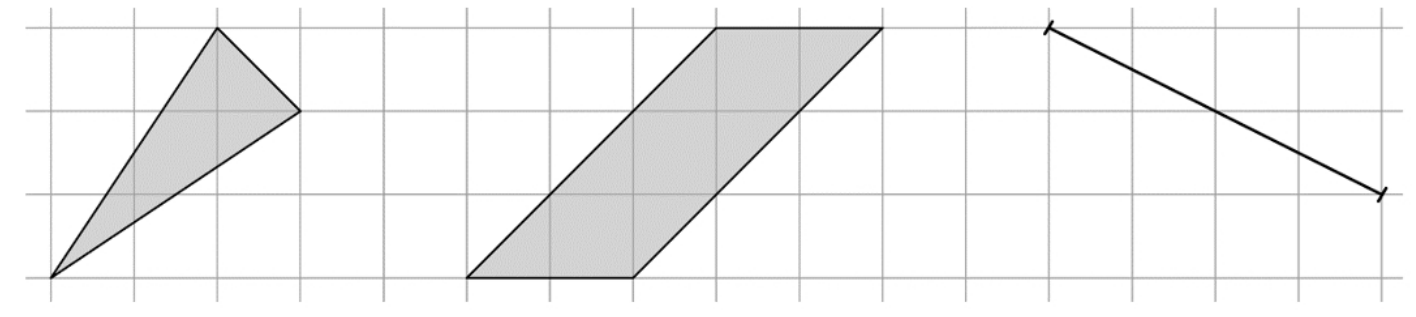

Figure 1: Given figures in task on axial symmetry in Test I (source: own data)

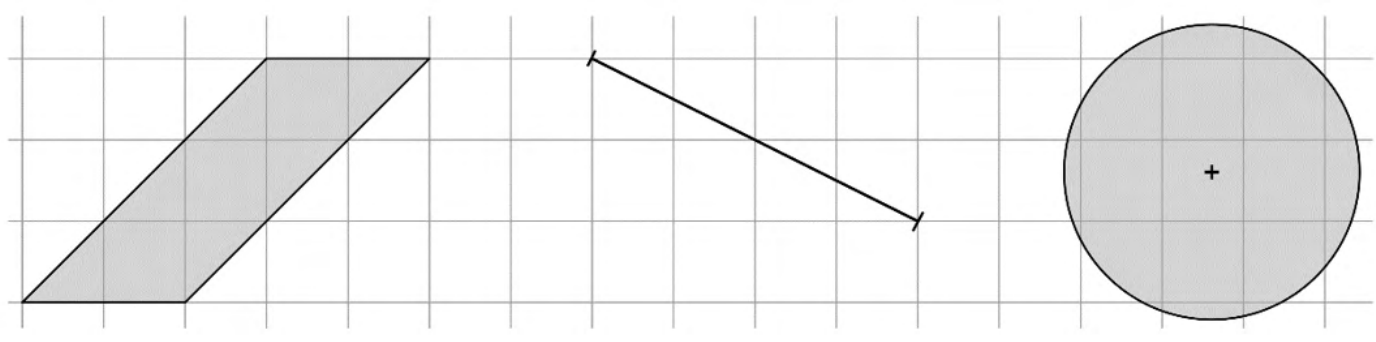

Figure 2: Given figures in task on axial symmetry in Tests II and III (source: own data)

In accordance with the Czech curriculum, it was possible to include central symmetry only in Tests II and III. We asked students to draw an image of a given pre-image in the central symmetry in a square grid. The pre-image in Test III (Figure 3, right) was slightly more complicated than the one in Test II (Figure 3, left), but they were quite similar. Vertices of the given pre-image and the centre point $S$ of symmetry were placed in lattice points in both tests. 

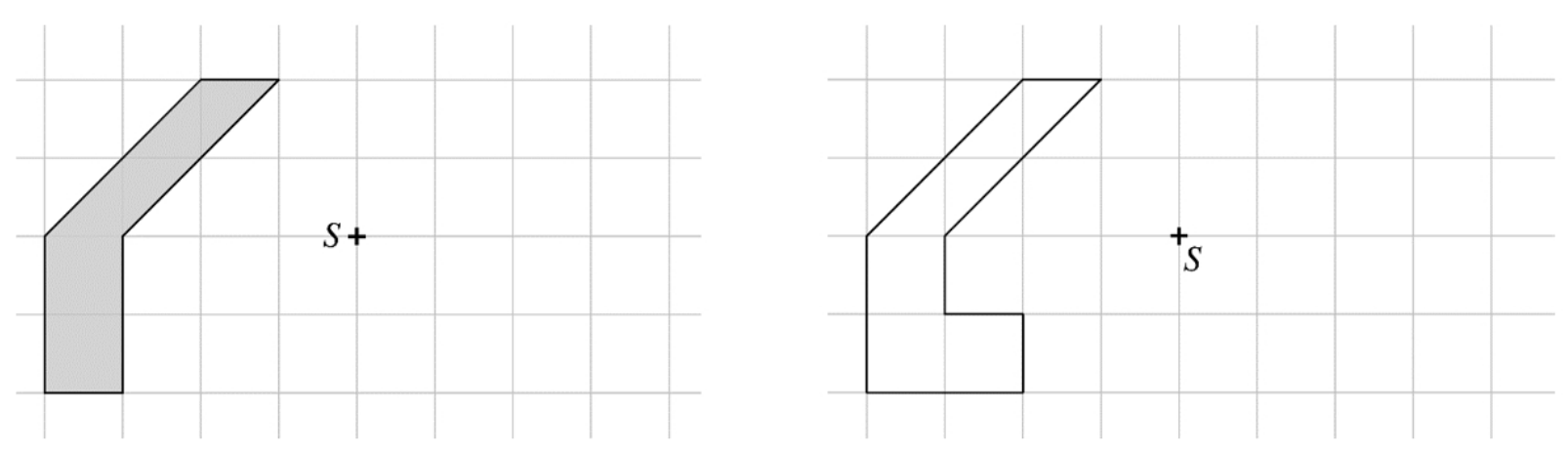

Figure 3: Given pre-image in task on central symmetry in Test II (left) and Test III (right) (source: own data)

The tests were administered to 1,458 Czech students who were selected on the basis of their availability. Test I was assigned to students of the first grade of lower secondary education (ISCED I level), Test II was assigned to students about to move from lower to upper secondary education (ISCED II level), and Test III was assigned to students about to move from upper secondary education to university (UNI) education (ISCED III level), and the pre-service teachers (PSTs) in their last two years of studies. The tests were solved anonymously; we registered only the gender of the respondents and the type of school - Tests I and II were solved by both basic school (BS) students and students of the corresponding grades of general secondary schools (GSS) ${ }^{4}$ (Table 1). All tests were personally administered by one of the research team members to ensure equal conditions. Students were encouraged to read the assignment carefully.

\begin{tabular}{|c|c|c|c|c|c|c|}
\hline Test & School type and grade (number of students) & M & $\mathbf{F}$ & Average age of students & Testing period & Total \\
\hline \multirow{2}{*}{1} & 6th grade of BS (177) & \multirow{2}{*}{225} & \multirow{2}{*}{280} & \multirow{2}{*}{11} & \multirow{2}{*}{2017 Sept.-Oct. } & \multirow{2}{*}{505} \\
\hline & corresponding grade of GSS (328) & & & & & \\
\hline \multirow{2}{*}{ II } & 9th grade of BS (180) & \multirow{2}{*}{231} & \multirow{2}{*}{206} & \multirow{2}{*}{15} & \multirow{2}{*}{2018 Apr.- June } & \multirow{2}{*}{437} \\
\hline & corresponding grade of GSS (257) & & & & & \\
\hline \multirow{3}{*}{ III } & last grade of GSS (311) & \multirow{3}{*}{291} & \multirow{3}{*}{225} & \multirow{2}{*}{19} & 2018 Apr. & \multirow{3}{*}{516} \\
\hline & 1st year of UNI (161) & & & & \multirow{2}{*}{2017 Oct.-Nov. } & \\
\hline & PSTs, i.e., 4th and 5th years of UNI (44) & & & $22-23$ & & \\
\hline Total & & & & & & 1,458 \\
\hline
\end{tabular}

$B S=$ basic school, GSS = general secondary school, UNI = university, $P S T S=$ pre-service teachers, $M=$ males, $F=$ females

Table 1: Overview of tested students (source: own data)

Students' solutions were coded for the purpose of evaluating the tests. In the task on axial symmetry (Figures 1 and 2), students' answers regarding the number of axes were coded with the corresponding numbers, including 0 for the answer "no axis". The code inf was used for the answer "infinite". In the task on central symmetry, the code $O K$ was used for the correctly drawn image; the code $c s$ was used when a student used the central symmetry, but he/she made an error and the image drawn was not congruent with the pre-image; the code as was used when a student drew the image in an axial symmetry; and the code $t$ was used when a student drew the image in a translation. If a student did not provide any solution, the code $M A$ (missing answer) was used.

The completed tests were naturally divided into groups according to the grade levels and type of schools of the respondents. The tests from every group were coded independently by various pairs of researchers. Any discrepancy in the coding of a specific student's solution was discussed among the whole research team until a consensus was reached.

The data obtained were subsequently statistically processed: tables of frequencies, relative frequencies, and for some pairs of characters contingency tables were also created. The $\chi^{2}$ test (at a significance level of 0.01 , unless otherwise stated) was primarily used to determine the various dependencies. Moreover, Fisher's exact test was used in cases where the input conditions for the $\chi^{2}$ test were not met, or the $\chi^{2}$ test worked out only at a significance level of 0.05 .

In addition to the presented statistics of students' solutions, we also focused on a deeper analysis of students' errors, their thought processes and possible causes of some misconceptions. For this purpose, we analysed, among other things, the results obtained with respect to commonly used Czech textbooks, in which we look for the causes of frequent

\footnotetext{
$4 \quad$ Czech elementary education takes nine years, usually from the ages of 6 to 15. Students typically attend a regular 9-year basic school, which is divided into two stages: primary and lower secondary stages. In addition, they have the option to apply to a 6- or 8-year general secondary school, which is a school with an entrance examination, after their 5 th or 7 th grade of elementary education. Students can also graduate from basic school and then continue their studies at a 4-year general secondary school or another type of upper secondary school. General secondary school graduates usually continue their studies at university. For a scheme of the Czech education system see, e.g., (Pont et al, 2013: 18).
} 
errors. We analysed four series of textbooks for primary education (published by Alter, Prometheus, SPN ${ }^{5}$ and Fraus), four series for lower secondary education including a special one for general secondary school (Prometheus for GSS, Prometheus for BS, Prodos and Fraus), and three series for upper secondary education (Prometheus, Didaktis and Fraus). In the textbooks, we focused mainly on the use of concept models, emphasis on prototypical positions of figures and the occurrence of tasks similar to those of our tests.

\section{RESULTS}

This section presents statistical overviews of student solutions to individual test tasks which were presented in the previous section. First, the overall success rate is introduced for each question. Furthermore, the most common student misconceptions and interesting answers are pointed out. Subsequently, the successes of groups of students differentiated according to school type and gender are compared.

In the tables with overviews of students' solutions (Tables 2-6), the mathematically correct answer is always given in the first column. The numbers of occurrences of individual solutions are given in relative frequencies. The column labelled $O A$ (Other Answer) always combines responses with low to negligible frequencies. The abbreviations BS (basic school), GSS (general secondary school), UNI (university) are used for the individual school types in the tables. Moreover, abbreviations PSTs (preservice teachers in their last two years of studies), M (males) and $\mathrm{F}$ (females) are used.

\section{Axial symmetry - an isosceles triangle}

The question on the number of symmetry axes of a given isosceles triangle was included only in Test I (Figure 1). The total success rate of students was high; the correct answer was given by more than $60 \%$ of respondents (Table 2 ).

\begin{tabular}{c|c|c|c|r|r|r|r}
\hline & & $\mathbf{1}$ & $\mathbf{0}$ & $\mathbf{2}$ & $\mathbf{3}$ & \multicolumn{1}{c}{ OA } & \multicolumn{1}{c}{ MA } \\
\hline \multirow{5}{*}{ Test I } & BS & 29.94 & 5.08 & 14.69 & 20.90 & 10.17 & 19.21 \\
\cline { 2 - 8 } & GSS & 76.83 & 8.84 & 4.88 & 3.35 & 1.22 & 4.88 \\
\cline { 2 - 8 } & $M$ & 57.78 & 8.89 & 6.67 & 9.78 & 5.78 & 11.11 \\
\cline { 2 - 8 } & F & 62.50 & 6.43 & 9.64 & 9.29 & 3.21 & 8.93 \\
\cline { 2 - 8 } & Total & 60.40 & 7.52 & 8.32 & 9.50 & 4.36 & 9.90 \\
\hline
\end{tabular}

Table 2: Isosceles triangle - relative frequencies of students' answers (source: own data)

Many students did not solve the task at all (almost 10\%). The most common incorrect answer was that the isosceles triangle has 3 axes of symmetry. This answer and missing answer were given mainly by BS students (about $20 \%$ in both cases). The dependence of the correct answer and the type of school that a student attends was verified by a $\chi^{2}$ test. Test criterion $K$ was significantly higher (105.655) than the critical value of 6.635 on the significance level of 0.01 . Therefore, the null hypothesis that the correct answer and the school type do not depend on each other was rejected. On the other hand, no significant statistical difference between males and females was found in this task.

\section{Axial symmetry - a rhomboid}

In the case of determining the number of symmetry axes for a given rhomboid, which was included in all three tests (Figures 1 and 2), the percentage of correct answers increased with age in our testing (Table 3). Conversely, the number of the most frequent incorrect answers ("2" and "4") decreased with increasing age, just as did the number of students who did not solve the task.

\begin{tabular}{|c|c|c|c|c|c|c|c|}
\hline & & 0 & 1 & 2 & 4 & $O A$ & MA \\
\hline \multirow{5}{*}{ Test I } & $B S$ & 7.91 & 5.65 & 21.47 & 32.20 & 14.69 & 18.08 \\
\hline & GSS & 41.46 & 10.67 & 24.70 & 12.20 & 5.49 & 5.49 \\
\hline & $M$ & 32.44 & 7.11 & 24.89 & 15.11 & 9.33 & 11.11 \\
\hline & $F$ & 27.50 & 10.36 & 22.50 & 22.50 & 8.21 & 8.93 \\
\hline & Total & 29.70 & 8.91 & 23.56 & 19.21 & 8.71 & 9.90 \\
\hline \multirow{5}{*}{ Test II } & $B S$ & 25.56 & 9.44 & 20.56 & 26.11 & 6.11 & 12.22 \\
\hline & GSS & 52.53 & 12.06 & 15.95 & 12.45 & 3.89 & 3.11 \\
\hline & $M$ & 40.26 & 9.09 & 18.18 & 18.61 & 5.19 & 8.66 \\
\hline & $F$ & 42.72 & 13.11 & 17.48 & 17.48 & 4.37 & 4.85 \\
\hline & Total & 41.42 & 10.98 & 17.85 & 18.08 & 4.81 & 6.86 \\
\hline \multirow{6}{*}{ Test III } & GSS & 56.27 & 12.22 & 17.68. & 8.68 & 3.22 & 1.93 \\
\hline & UNI & 50.93 & 13.66 & 16.15 & 12.42 & 3.11 & 7.45 \\
\hline & PSTS & 61.36 & 20.45 & 13.64 & 2.27 & 0.00 & 2.27 \\
\hline & $M$ & 54.98 & 11.68 & 18.56 & 7.56 & 3.09 & 4.12 \\
\hline & $F$ & 55.11 & 15.56 & 14.67 & 8.89 & 2.67 & 3.11 \\
\hline & Total & 55.04 & 13.37 & 16.86 & 8.14 & 2.91 & 3.68 \\
\hline
\end{tabular}

Table 3: Rhomboid - relative frequencies of students' answers (source: own data)

5 SPN - State Pedagogical Publishing House, in Czech: Státní Pedagogické Nakladatelství. 
We observe a higher success rate of GSS students than BS in Tests I and II. In both cases, the dependence of the correct answer and the type of school was again proved by a $\chi^{2}$ test $(K=61.987$ in Test I, $K=31.74$ in Test II). In Test III, PSTs were the most successful (Table 3), but the dependence of the correct answer on the group of students is not statistically significant.

No statistically significant gender differences were generally demonstrated in this task in the whole sample. However, Fisher's exact test showed a statistical dependence in favour of males (the two-tailed $p$-value equals 0.0118 ) in Test I in the BS group.

In Test I, we were able to further investigate how individual students attempted to solve the number of axes of the isosceles triangle and the rhomboid, thus with the axial symmetry properties of two different polygons. The $\chi^{2}$ test pointed out a strong dependence between the correct solutions in both tasks (test criterion $K=100.737$, which is significantly higher than the critical value). The results showed a significant connection exists (Moravcová et al, 2019).

\section{Axial symmetry - a line segment}

The number of symmetry axes of a given line segment was also included in all three tests (Figures 1 and 2). The success rate of students in this task was relatively low and increased only slightly with age; it reached approximately $26 \%$ in Test III (Table 4). However, with increasing age, the number of the most frequent incorrect answers, i.e., " 1 " axis of symmetry, also increased. It is also worth noting that in Test I, 14\% of respondents answered that the line segment has no axis of symmetry.

In the task on the line segment, we again observe a higher success rate of GSS students than BS ones in Tests I and II (Table 4). In Test I, the relationship between choosing the correct answer and the group was demonstrated by the $\chi^{2}$ test $(K=13.97)$. In Test II, this dependence was not statistically significant. PSTs were the most successful in Test III again. According to Fisher's exact test, the relationship between this group and the correct answer is statistically significant $(p$-value $=0.0497)$.

\begin{tabular}{|c|c|c|c|c|c|c|c|}
\hline & & 2 & 0 & 1 & 4 & $O A$ & MA \\
\hline \multirow{5}{*}{ Test I } & $B S$ & 14.12 & 23.16 & 32.20 & 6.21 & 4.52 & 19.77 \\
\hline & GSS & 28.96 & 9.15 & 52.44 & 0.91 & 3.35 & 5.18 \\
\hline & $M$ & 25.78 & 16.00 & 40.89 & 3.56 & 2.67 & 11.11 \\
\hline & $F$ & 22.14 & 12.50 & 48.93 & 2.14 & 4.64 & 9.64 \\
\hline & Total & 23.76 & 14.06 & 45.35 & 2.77 & 3.76 & 10.30 \\
\hline \multirow{5}{*}{ Test II } & $B S$ & 22.22 & 6.67 & 51.11 & 2.22 & 6.11 & 11.67 \\
\hline & GSS & 25.68 & 4.67 & 61.48 & 0.00 & 5.84 & 2.33 \\
\hline & $M$ & 25.54 & 6.93 & 54.11 & 0.43 & 5.63 & 7.36 \\
\hline & $F$ & 22.82 & 3.88 & 60.68 & 1.46 & 6.31 & 4.85 \\
\hline & Total & 24.26 & 5.49 & 57.21 & 0.92 & 5.95 & 6.18 \\
\hline \multirow{6}{*}{ Test III } & GSS & 25.08 & 1.29 & 66.88 & 0.96 & 3.86 & 1.93 \\
\hline & UNI & 24.22 & 3.73 & 66.46 & 0.00 & 0.62 & 4.97 \\
\hline & PSTS & 38.64 & 4.55 & 56.82 & 0.00 & 0.00 & 0.00 \\
\hline & $M$ & 30.93 & 1.03 & 62.89 & 0.34 & 2.06 & 2.75 \\
\hline & $F$ & 19.56 & 4.00 & 69.78 & 0.89 & 3.11 & 2.67 \\
\hline & Total & 25.97 & 2.33 & 65.89 & 0.58 & 2.52 & 2.71 \\
\hline
\end{tabular}

Table 4: Line segment - relative frequencies of students' answers (source: own data)

In all three tests, males were more successful (Table 4). However, a statistically significant dependence of the correct answer in favour of males was demonstrated only in Test III (the test criterion $K$ of $\chi^{2}$ test equals 8.54).

\section{Axial symmetry - a circle}

Students were asked about the number of symmetry axes of a given circle in Tests II and III (Figure 2). This task was the most successful overall (Table 5). The most frequent incorrect answers were " 0 ", "1", " 2 " and " 4 " axes of symmetry.

\begin{tabular}{|c|c|c|c|c|c|c|c|c|}
\hline & & $\inf$ & 0 & 1 & 2 & 4 & $O A$ & MA \\
\hline \multirow{5}{*}{ Test II } & $B S$ & 51.67 & 10.00 & 8.89 & 5.00 & 1.67 & 6.11 & 16.67 \\
\hline & GSS & 88.72 & 1.95 & 3.50 & 0.00 & 0.78 & 1.56 & 3.50 \\
\hline & $M$ & 73.59 & 4.76 & 7.36 & 0.87 & 0.43 & 3.46 & 9.52 \\
\hline & $F$ & 73.30 & 5.83 & 3.88 & 3.40 & 1.94 & 3.40 & 8.25 \\
\hline & Total & 73.46 & 5.26 & 5.72 & 2.06 & 1.14 & 3.43 & 8.92 \\
\hline \multirow{6}{*}{ Test III } & GSS & 86.50 & 1.61 & 2.57 & 3.22 & 0.96 & 2.25 & 2.89 \\
\hline & UNI & 85.09 & 2.48 & 1.54 & 1.54 & 0.00 & 1.54 & 6.83 \\
\hline & PSTS & 97.73 & 0.00 & 0.00 & 2.27 & 0.00 & 0.00 & 0.00 \\
\hline & $M$ & 89.00 & 2.06 & 1.03 & 3.09 & 1.03 & 1.03 & 2.75 \\
\hline & $F$ & 84.44 & 1.33 & 3.56 & 2.22 & 0.00 & 3.11 & 5.33 \\
\hline & Total & 87.02 & 1.74 & 2.13 & 2.71 & 0.58 & 1.94 & 3.88 \\
\hline
\end{tabular}

Table 5: Circle - relative frequencies of students' answers (source: own data) 
In Test II, GSS students were again more successful than BS ones. The $\chi^{2}$ test confirmed the significant dependence of the school type and the choice of the correct answer. In Test III, PSTs were the most successful with a result of almost $100 \%$. Only 1 student of this group wrote that the circle has only 2 axes of symmetry. The dependence of the answer on the type of study was also statistically confirmed in this group ( $\chi^{2}$ test criterion $K=4.88$ is higher than the critical value 3.841 on the significance level of 0.05 and the two-tailed $p$-value of the Fisher's exact test equals 0.02).
There were no statistically significant differences between males and females in this task in total. A slight difference in favour of males was observed only in the GSS group.

\section{Central symmetry}

In the last monitored task, students were asked to draw an image of a given pre-image in the central symmetry in a square grid (Figure 3 ).

\begin{tabular}{|c|c|c|c|c|c|c|c|}
\hline & & OK & CS & as & $t$ & $O A$ & MA \\
\hline \multirow{5}{*}{ Test II } & $B S$ & 38.33 & 5.00 & 40.00 & 5.00 & 1.67 & 10.00 \\
\hline & GSS & 48.25 & 5.45 & 35.02 & 4.67 & 2.33 & 4.28 \\
\hline & $M$ & 45.02 & 6.49 & 35.50 & 3.90 & 0.87 & 8.23 \\
\hline & $F$ & 43.20 & 3.88 & 38.83 & 5.83 & 3.40 & 4.85 \\
\hline & Total & 44.16 & 5.26 & 37.07 & 4.81 & 2.06 & 6.64 \\
\hline \multirow{6}{*}{ Test III } & GSS & 67.85 & 2.25 & 28.61 & 0.32 & 0.32 & 0.64 \\
\hline & UNI & 67.08 & 2.48 & 29.19 & 0.00 & 0.00 & 1.24 \\
\hline & PSTS & 86.36 & 0.00 & 11.36 & 0.00 & 0.00 & 2.27 \\
\hline & $M$ & 73.20 & 2.06 & 23.37 & 0.00 & 0.34 & 1.03 \\
\hline & $F$ & 64.00 & 2.22 & 32.44 & 0.44 & 0.00 & 0.89 \\
\hline & Total & 69.19 & 2.13 & 27.33 & 0.19 & 0.19 & 0.97 \\
\hline
\end{tabular}

Table 6: Central symmetry - relative frequencies of students' solutions (source: own data)

The image was drawn correctly by almost $45 \%$ of students in Test II and almost $70 \%$ of students in Test III (Table 6). The most frequent error was using a different isometry. The substitution of an axial symmetry (code as) predominated. Almost $5 \%$ of respondents in Test II used a translation (code $t$ ). GSS students were more successful in Test II. The $\chi^{2}$ test confirmed the statistical dependence of the school type and the correct solution only on the significance level of 0.05 , so the dependence was also verified by Fisher's exact test ( $p$-value $=0.0407)$. In Test III, PSTs were again the most successful and the dependence was confirmed here by $\chi^{2}$ test $(K=6.6576)$.

In Test III, there was a statistically significant dependence of the correct solution on gender in favour of males (for all respondents, the $\chi^{2}$ test comes out only on the significance level of 0.05 , however, the two-tailed $p$-value of the Fisher's exact test equals 0.0272). Nevertheless, this result was affected by the results of the GSS group (only for this group, the $\chi^{2}$ test criterion $K$ equals 17.177$)$. In Test II, males were slightly more successful, but no statistically significant difference was observed.

\section{DISCUSSION}

First, we analyse the results of students in individually presented tasks with respect to the research questions asked. Then we will think about the issue of gender and the difference between BS and GSS students.

\section{Do students recognize that a rhomboid is not an axially symmetrical figure?}

We asked all the age groups of students tested about the number of symmetry axes of a given rhomboid. In Test I, we observe a high number of incorrect answers. This number decreases with increasing age. Nevertheless, $45 \%$ of students did not successfully solve the task in Test III. Here we can observe a misconception: 'a rhombus is an axially symmetrical figure.' Even worse results in research into the same problem were obtained by Aktaş and Ünlü (2017), who found that only $6.4 \%$ of respondents described a rhomboid as an axially asymmetrical figure.

Many students drew axes of symmetry in the picture (Figure 4). Thanks to this, and also from interviews from the pre-test, we know that the symmetry axis of the rhomboid is most often considered a horizontal median (those who answered " 1 " axis of symmetry), both medians (those who answered " 2 " axes of symmetry), or medians and diagonals (those who answered "4" axes of symmetry). Answer " 2 " was generally one of the most frequent incorrect answers, as in other research (Aktaş and Ünlü, 2017; Son, 2006). Leikin, Berman and Zaslavsky (2000) also encountered medians as the axes of symmetry of a rhomboid.

One of the possible causes of these errors, especially in Test I, is the fact that the medians or diagonals divide the rhomboid into two identical figures. A task such as being asked to divide a given figure into two identical ones by a straight line is common in primary school. Hacısalihoğlu-Karadeniz et al (2015) also encountered this reasoning among pre-service teachers. Another reason for the errors in Test I may be the fact that students rarely encounter non-models while they are getting acquainted with axial symmetry at school (Hejný, 2012). In addition, a rhomboid is specific in that it is a nonmodel of an axially symmetrical figure as well as a model of a centrally symmetrical figure. In our opinion, students should encounter figures such as these while in primary education, i.e., at the time when they first encounter axial symmetry in school. However, we did not find a rhomboid or another figure 


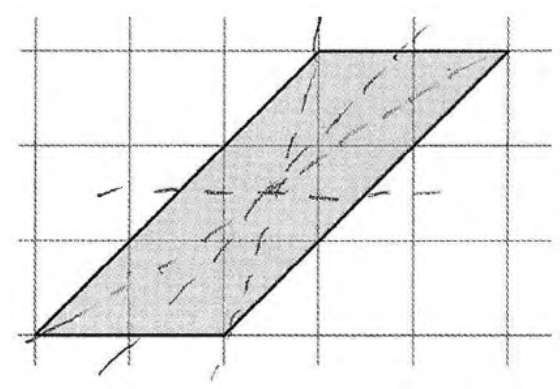

Figure 4: Four "symmetry axes" of the given rhomboid, student's incorrect solution (source: own data)

with these properties in the given context in the analysed textbooks for primary school. It appears only in textbooks for the next level of education but not with sufficient emphasis; the exception is the textbook (Vondra, 2013). The fact that students work more with a rhomboid in lower and upper secondary schools is probably why students were more successful in Tests II and III at this task.

Students who tried to complete the axes of symmetry proceeded to solve the problem procedurally. While this led some of them to find the correct solution, relying on procedural methods rather than conceptual understanding can lead to the incorrect solution (Son, 2006).

For comparison, in Test I, students were also asked about the number of symmetry axes of an isosceles triangle, which is a model of an axially symmetrical figure which is found in all the analysed textbooks. This task had a significantly higher success rate (more than $60 \%$ ) than the task about the rhomboid (less than 30\%). Students might have been confused that the triangle was not placed in a prototypical position (i.e., with a horizontally placed base). The most common incorrect answer was " 3 " axes of symmetry; students likely confused an isosceles triangle with an equilateral one. According to several researches (Tirosh et al, 2011; Budínová, 2018) students' concept of a triangle is associated with an equilateral one in a prototypical position. The picture in our test was contrary to the students' experience. The confirmed dependence of the correct answers in the test task on the number of symmetry axes of the given triangle and rhomboid in Test I indicates that students who solved the task about the rhomboid have a strong concept of axial symmetry.

\section{Are students able to find all symmetry axes of a line segment?}

The task on the number of symmetry axes of a given line segment seems to be problematic. The low success rate confirmed our assumption that the task was atypical for students. According to our analysis of textbook series, students usually encounter only 2D figures as examples of axially symmetrical figures in Czech primary school textbooks. This is probably the reason why over $10 \%$ of students did not solve the task at all in Test I. Even at higher education levels, it is a common task to construct the image of a line segment, straight line or half-line in axial symmetry, but not to find the symmetry axis/axes of these figures. In the analysed textbooks, we found only one task with a similar topic (Figure 5) in the exercise book (Gazárková, Melicharová and Vokřínek, 2013) for upper secondary school. We are not aware of any other research concerning this problem.

The points $A, B, A^{\prime}, B^{\prime}$ are given. Construct the axis 0 of an axial
symmetry $O(0)$ in which $A \rightarrow A^{\prime}, B \rightarrow B^{\prime}$.
$\begin{aligned} & \text { a) } \\ & \times B_{A=B^{\prime}}\end{aligned}$

Figure 5: Task from a Czech exercise book, free translation (source: Gazárková, Melicharová and Vokř́nek, 2013, p. 140)

Students often stated that the line segment has " 1 " axis of symmetry. The number of these responses even increased to almost $66 \%$ in Test III. The answer " 1 " is offered because students from the primary school encounter the term axis of a line segment. The axis of a line segment is a straight line which is perpendicular to the line segment and passing through its midpoint. Each line segment has exactly one axis, but two axes of symmetry. The difference between the axis of a line segment and the symmetry axis of a line segment (Figure 6) then disappears in students' minds. This confusion of two different concepts can be unhappily supported in the educational process by formulations/questions from textbooks such as the following: 'Is the straight line $o$ [perpendicular to the centre of the line segment] the axis of symmetry of the $A B$ line segment?' (Odvárko and Kadleček, 2011: 36).

Despite the low number of correct answers, we were pleased that about $25 \%$ of students did not let themselves be fooled and thought about the problem. We know from the pre-test interviews that they were often unsure of the correct answer "2", but they were able to think about the concept of axial symmetry and consider different answers. Some of them supplemented their answer with comments such as: 'Theoretically 2 , if a straight line is its own axis of symmetry.' 

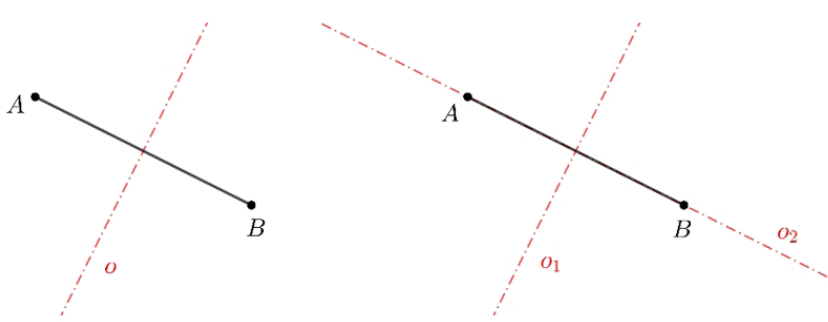

Figure 6: Illustration of the difference between the axis (left) and the symmetry axes (right) of the line segment $A B$ (source: own picture)

With regard to the cognitive development of students, we do not perceive it as a problem that a large number of students in Test I were unable to solve this atypical task. The problem is that the relative number of correct answers hardly changed in Tests II and III. On the contrary, the misconception that a line segment has only one axis of symmetry clearly strengthened with increasing age (45\% in Test I, $57 \%$ in Test II, $66 \%$ in Test III). This may indicate a misunderstanding of the concept of axial symmetry. Unfortunately, this error was also made by pre-service teachers.

\section{Do students know that the number of symmetry axes of a circle is infinite?}

The task on the number of symmetry axes of a circle is a standard task, found in almost all the analysed textbooks. Even so, we are not aware of a similar study that has dealt with this problem.
We assumed we would observe the misconception 'a circle has only two axes of symmetry (horizontal and vertical)', which we encountered in our practical teaching experience; but it was not confirmed here. The answer " 2 ", as well as other incorrect answers, was chosen by only a small number of the respondents. However, based on the student sketches in the tests, we can say that those who chose the answer " 2 " actually considered the vertical and horizontal axes of symmetry. In the case of the answer " 1 ", students preferred the vertical axis; in the case of answer " 4 ", they moreover considered the axes forming a $45^{\circ}$-angle with the horizontal/vertical straight line (Figure 7). According to $10 \%$ of BS students in Test II, the given circle is not an axially symmetrical figure - they wrote that it has " 0 " axes of symmetry. However, this idea probably disappears with increasing age; it was stated by less than $2 \%$ of respondents in Test III.

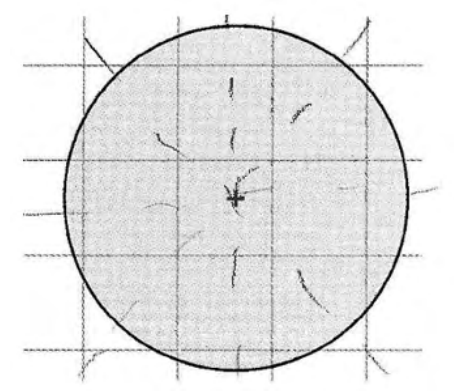

Figure 7: Four symmetry axes of the given circle, student's incorrect solution (source: own data)

There were also isolated interesting opinions in the tests; e.g., "360", which is probably related to the degree size of the full angle. Some students did not answer the given question exactly, but their answer was very precise from a mathematical point of view: '[symmetry axes of the given circle are] all straight lines that pass through the centre of the circle'.

\section{Are students able to construct an image of a given figure in central symmetry?}

Very similar figures were assigned in Tests II and III in the task on central symmetry (Figure 3). Students were asked to draw their images in central symmetry with the given centre $S$, with the help of a pre-drawn grid (the vertices of the figure and the centre of symmetry were grid points).

About $44 \%$ of Test II respondents and almost $70 \%$ of Test III respondents solved the task correctly, which is a very nice result. Several other students worked correctly with the concept of central symmetry, but they made more significant inaccuracies and did not draw the identical figure (the code $c s$ ). Aktaş and Ünlü (2017) obtained worse results in 8th grade students in a similar study; only $36 \%$ of students drew the image of the given simple pre-image in a central symmetry correctly or almost correctly.

One specific situation (the code as) significantly dominates among the incorrect solutions: students drew a vertical axis in the picture and constructed an image of the given figure in axial symmetry. In the vast majority of cases, they drew this axis passing through the given point $S$ (Figure 8); other positions of the axis occasionally occurred. Several students first constructed an image in axial symmetry, but then realized their error and either corrected themselves or at least mentioned it in the attached commentary. One student solved the situation by additionally modifying the assignment (Figure 9).

Many respondents drew auxiliary lines through the vertices of the given figure and the centre $S$, even if they did not use these lines and drew the image in axial symmetry (Figure 10).

One of the possible reasons why students confused central and axial symmetry may be the fact that in mathematics teaching, axial symmetry is revised immediately before the introduction of central symmetry. Students fix in their minds the first information they encounter on a new topic (Ebbinghaus, 1913; Škoda and Doulík, 2011), or they do not fully understand the 


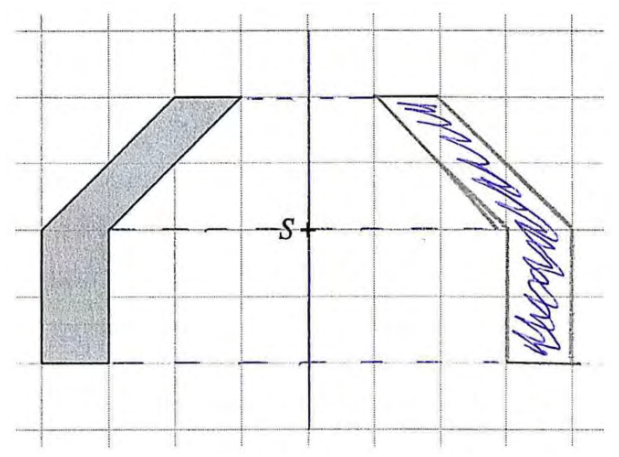

Figure 8: Use of the vertical axis in the test task on central symmetry, student's incorrect solution (source: own data)

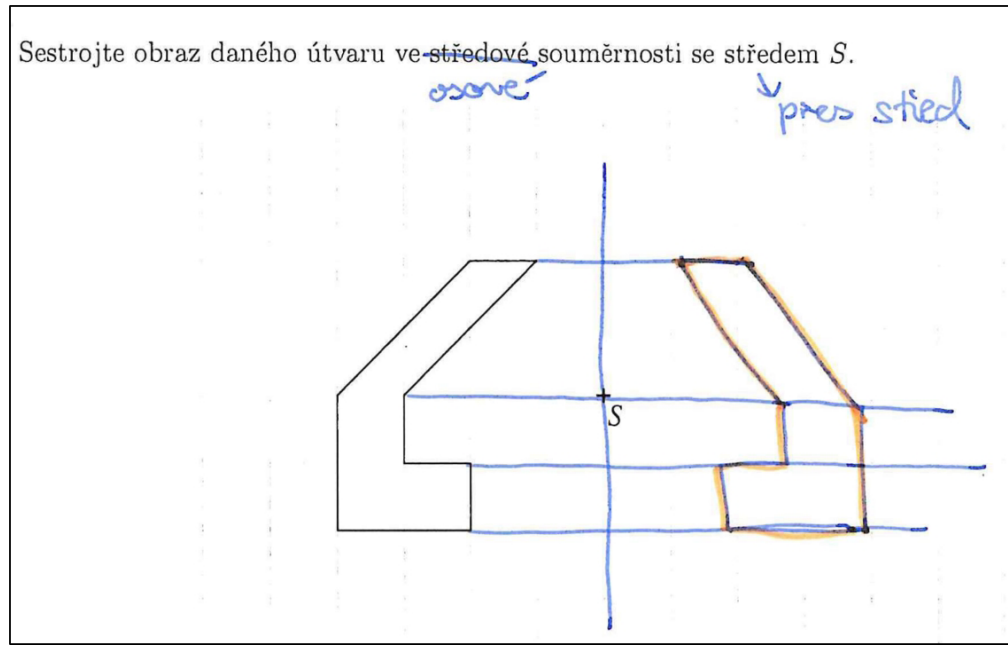

Figure 9: Student's incorrect solution and subsequent change of the assignment ${ }^{6}$ (source: own data)

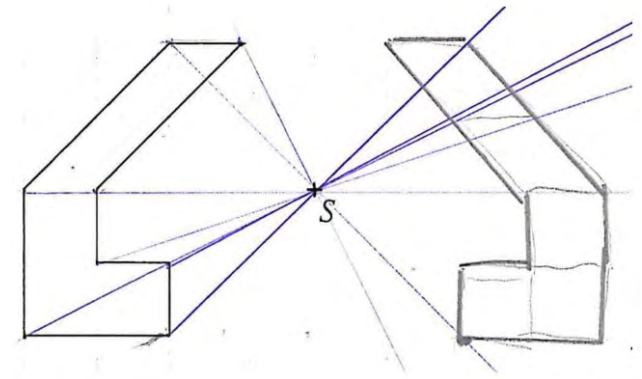

Figure 10: Student's incorrect solution in spite of the use of adequate auxiliary lines (source: own data)

concept of central symmetry and remain only at the level of an isolated model (Hejný, 2012). Also, in subsequent levels of education, central and axial symmetry are taught at the same time, often in one lesson or during one week. Son (2006) and Jagoda (2008) also encountered a confusion of axial and central symmetry among students.

The preference of the vertical axis could be caused by the fact that the vertical axis is predominately used in the pictures on the topic of axial symmetry in most of the analysed textbooks. The preference for the vertical (or horizontal) axis is in agreement with researches (Jagoda, 2008) and (Kambilombilo and Sakala, 2015), in which students had difficulty drawing images in axial symmetry with an oblique axis.

Almost 5\% of students used a translation in Test II. Except for one situation, students translated the given figure horizontally to the right, most often by 3, 3.5 or 4 squares of the grid (Figure
11 ); or so that the point $S$ was approximately the centre of the translation vector. While we expected the confusion between central and axial symmetry, we were surprised by the confusion of central symmetry and translation, as the pupils do not usually encounter a translation until upper secondary school. They may have been led to this solution by the fact that they could not remember the concept of central symmetry and they knew that axial symmetry would be wrong, so they simply tried something else. However, only one respondent in Test III drew a translated image.

Let's return to comparing the success rate by gender and between the BS and GSS groups. In most test tasks, males were better; however, the differences between males and females in many tasks were not statistically significant. The significant dependence of the choice of the correct answer on gender in favour of males was confirmed only in the case of $6 \quad$ Free translation of the student's version of the assignment: 'Construct an image of the given pre-image in axial symmetry through the centre $S$.' 


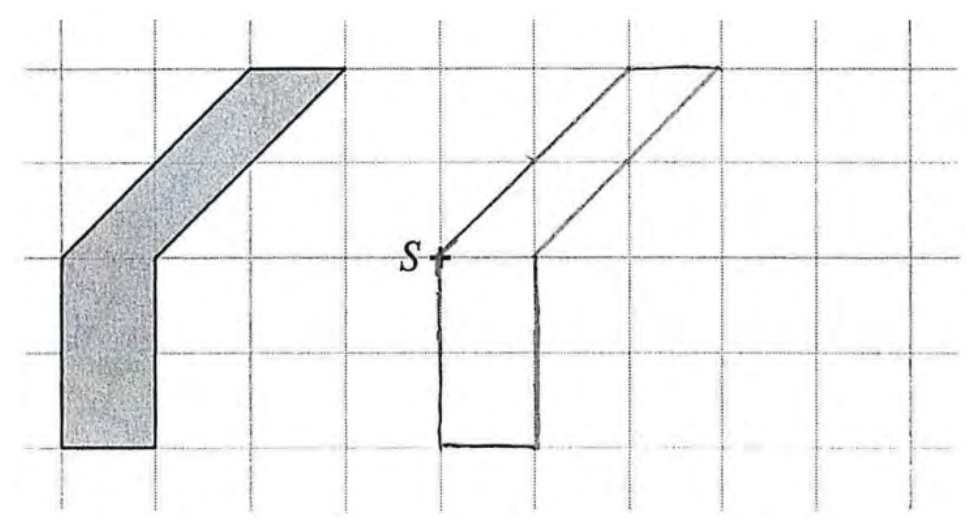

Figure 11: Student's incorrect solution of test task on central symmetry using translation (source: own data)

axial symmetry of the line segment in Test III, and in the task on central symmetry in Test III. This disproportion in favour of males is in agreement with most previous research (e.g., Smith and Walker, 1988), however, in our testing the overall difference between the males and females was not significant, which is in agreement with the research of Kambilombilo and Sakala (2015). Better results of the males obtained in some tasks may be related to a more positive attitude of the males to mathematics (Emanovský and Gonda, 2020; Ganley and Lubienski, 2016).

Moreover, a comparison of the success rate between BS and GSS students was possible in Tests I and II. GSS students were more successful in all test tasks than BS ones. In all tasks, except for the number of symmetry axes of the line segment in Test II, the hypothesis that the type of school and the choice of the correct answer do not depend on each other can be rejected. The higher success rate of GSS students is probably related to the fact that GSS are selective schools with an entrance exam and studying at them is more demanding (Martinková, Hladká and Potužníková, 2020); they can also use specific textbooks intended for GSSs.

It is positive that PSTs were the most successful of all test groups. On the other hand, there was a certain error rate even among them. Other researches (e.g., Ada and Kurtuluş, 2010; Hacısalihoğlu-Karadeniz et al, 2015; Kambilombilo and Sakala, 2015; Hacısalihoğlu-Karadeniz, Kaya and Bozkuş, 2017; Son, 2006; Thaqi, Giménez and Rosich, 2011) have also pointed out pre-service teachers' problems with the concepts of symmetry.

The causes of students' errors can be various; it is difficult to identify all of them. One of the possible negative influences can be inappropriately designed textbooks, as teachers and students work with them during the teaching and learning process. Primary school teachers in particular often consider the textbook to be a sufficient resource for preparation for teaching lessons. The influence of textbooks was also mentioned by Aktaş and Ünlü (2017). Other causes may be, e.g., the influence of the teacher (Aktaş and Ünlü, 2017; Hacısalihoğlu-Karadeniz et al, 2015; Hacısalihoğlu-Karadeniz, Kaya and Bozkuş, 2017; Son, 2006), the socio-cultural environment of students (e.g., Brand, Glasson and Green, 2010; Maaz et al, 2008), the popularity of geometry with students (e.g., Rendl and Vondrová, 2013), etc.

In ourresearch, weobservethatstudentshavethegreatestproblems with atypical tasks. Similar tasks need to be included more often in textbooks and in the teaching process (Kambilombilo and Sakala, 2015), as they practise and examine mainly conceptual knowledge. A greater error rate occurs particularly when there is a lack of conceptual understanding of the topic. Students proceed procedurally rather than conceptually (they try to draw axes), they do not think about the concept of symmetry and they do not find all solutions. The students do not connect process and concept, i.e., they do not have developed the symmetry procept (Hejný, 2000). These errors do not decrease with increasing age and thus misconceptions arise in students' minds. Therefore, it is necessary to introduce more atypical problems and to place more emphasis on conceptual understanding in the training of pre-service teachers (Hacisalihoğlu-Karadeniz, Kaya and Bozkuş, 2017; Son, 2006; Thaqi, Giménez and Rosich, 2011).

\section{CONCLUSION}

Students' understanding of isometries is a precursor to understanding other mathematical concepts. Isometries are the easiest geometrical transformations and transformations are encountered by people in daily life. Therefore, we consider teaching and understanding the concepts related to isometries to be important at all education levels.

In the years 2017-2018, we carried out an extensive testing of Czech students in order to determine their understanding of certain geometrical concepts. In this paper, we have analysed the students' answers to the test tasks concerning axial and central symmetry in detail and have thought about the possible causes of frequent errors.

With respect to the research questions asked, we can say that the tested students identified typical axially symmetrical figures (an isosceles triangle, a circle) and most of them correctly determined the number of symmetry axes of these figures. Conversely, students had problems recognizing a given rhomboid (i.e., a centrally, but not axially, symmetrical figure) as a non-model of an axially symmetrical figure. Furthermore, students did not perceive that a line segment has two different axes of symmetry. However, they knew that a circle has an infinite number of symmetry axes. A significant number of the students confused central symmetry for axial symmetry in the construction task. These students preferred a vertical axis of symmetry. From a gender point of view, the results speak slightly in favour of males. This difference is most obvious in the highest age category of tested students (from 19 to 23 years). A significant difference in favour of general secondary school students at the expense of basic school students was confirmed.

Our pedagogical recommendations resulting from the above are: it is necessary to place greater emphasis on non-models and figures 
in non-prototypical positions in textbooks and teaching; during mathematics lessons, it is also necessary to work with atypical tasks (e.g., to look into symmetries of not only 2D, but also 1D figures), even in higher grades it is necessary to include elementary tasks on symmetries in teaching, and last but not least, greater emphasis should be placed on the spiral curriculum throughout the educational process and on the conceptual knowledge of preservice teachers.

In further research, we continue to explore students' understanding of other geometrical concepts. Moreover, we observe the relationship between students' concepts and how students like geometry. Among other things, we also focus on the improvement of the training of pre-service mathematics teachers and the connection between conceptual and procedural knowledge.

\section{ACKNOWLEDGEMENT}

The paper has been supported by the project PROGRES Q17 Teacher preparation and teaching profession in the context of science and research and by Charles University Research Centre program No. UNCE/HUM/024.

\section{REFERENCES}

Ada, T. and Kurtuluş, A. (2010) 'Students' misconceptions and errors in transformation geometry', International Journal of Mathematical Education in Science and Technology, Vol. 41, No. 7, pp. 901-909. https://doi.org/10.1080/0020739X.2010.486451

Adolphus, T. (2011) 'Problems of Teaching and Learning of Geometry in Secondary Schools in Rivers State, Nigeria', International Journal of Emerging Sciences, Vol. 1, No. 2, pp. 143-152.

Aktaş, G. S. and Ünlü, M. (2017) 'Understanding of Eight Grade Students about Transformation Geometry: Perspectives on Students' Mistakes', Journal of Education and Training Studies, Vol. 5, No. 5, pp. 103-119. https://doi.org/10.11114/jets.v5i5.2254

Brand, B. R., Glasson, G. E. and Green, A. M. (2010) ‘Sociocultural Factors Influencing Students' Learning in Science and Mathematics: An Analysis of the Perspectives of African American Students', School Science and Mathematics, Vol. 106, No. 5, pp. 228-236. https://doi. org/10.1111/j.1949-8594.2006.tb18081.x

Budínová, I. (2018) 'Vytváření představ základních geometrických pojmů u žaků prvního stupně zakladní školy: trojúhelník a kruh', Učitel matematiky, Vol. 26, No. 1, pp. 1-11.

Ebbinghaus, H. (1913) Memory: A contribution to experimental psychology. New York: Teachers College.

Emanovský P. and Gonda D. (2020) 'Mathematical Calculations within Physics Lessons and Their Popularity Among Learners', Journal on Efficiency and Responsibility in Education and Science, Vol. 13, No. 4, pp. 204-211. http://dx.doi.org/10.7160/eriesj.2020.130404

Ganley, C. M. and Lubienski S. T. (2016) 'Mathematics confidence, interest, and performance: Examining gender patterns and reciprocal relations', Learning and Individual Differences, Vol. 47, pp. 182-193. https://doi.org/10.1016/j.lindif.2016.01.002

Gazárková, D., Melicharová, S. and Vokř́nek, R. (2013) Matematika pro střední školy, 3. dill: Planimetrie - Pracovni sešit, Brno: Didaktis.

Geçici, M. E. and Aydın, M. (2020) 'Determining the geometry problem posing performances of eighth grade students in different problem posing situations', International Journal of Contemporary Educational Research, Vol. 7, No. 1, pp. 1-17. https://doi. org/10.33200/ijcer.575063

Gray, E. M. and Tall, D. O. (1994) 'Duality, Ambiguity, and Flexibility: A 'Proceptual" View of Simple Arithmetic', Journal for Research in Mathematics Education, Vol. 25, No. 2, pp. 116-140. https://doi. org/10.2307/749505

Hacısalihoğlu-Karadeniz, M., Baran, T., Bozkuş, F. and Gündüz, N. (2015) 'Difficulties of prospective elementary mathematics teachers' regarding to reflection symmetry', Turkish Journal of Computer and Mathematics Education, Vol. 6, No. 1, pp. 117-138. https://doi. org/10.16949/turcomat.71538
Hacısalihoğlu-Karadeniz, M. H., Kaya, T. B. and Bozkuş, F. (2017) 'Explanations of prospective middle school mathematics teachers for potential misconceptions on the concept of symmetry', International Electronic Journal of Elementary Education, Vol. 10, No. 1, pp. 7182. https://dx.doi.org/10.26822/iejee.2017131888

Halas, Z., Robová, J., Moravcová, V. and Hromadová, J. (2019) 'Pupils' concepts of the trapezoid at the end of lower secondary level education', Open Education Studies, Vol. 1, No. 1, pp. 184-197. https://doi.org/10.1515/edu-2019-0013

Halas, Z., Moravcová, V., Robová, J. and Hromadová, J. (2020) 'Are students able to identify an image of a straight line in rotation?', Proceedings of the 17th International Conference on Efficiency and Responsibility in Education (ERIE 2020), Prague, pp. 69-75.

Hejný, M. (2000) 'Budování geometrických proceptů, 7. setkáni učitelů všech typů a stupňn škol, Mariánské Lázně, pp. 11-17.

Hejný, M. (2012) 'Exploring the Cognitive Dimension of Teaching Mathematics through Scheme-oriented Approach to Education', Orbis Scholae, Vol. 6, No. 2, pp. 41-55. https://doi. org/10.14712/23363177.2015.39

Herendiné-Kónya, E. (2008) 'Geometrical transformations and the concept of cycling ordering', in Maj, B. Pytlak, M. and Swoboda, E. (ed.) Supporting Independent Thinking Through Mathematical Education, Rzeszów: Wydawnictwo Uniwersytetu Rzeszowskiego, pp. 102-108.

Hiebert, J. and Lefevre, P. (1986) 'Conceptual and procedural knowledge in mathematics: An introductory analysis', in Hiebert, J. (ed.) Conceptual and procedural knowledge: The case of mathematics, Hillsdale, NJ: Lawrence Erlbaum Associates, pp. 1-27.

Hollebrands, K.F. (2004) 'High School Students' Intuitive Understandings of Geometric Transformations', Mathematics Teacher, Vol. 97, No. 3, pp. 207-214.

Fryer, R. G. and Levitt, S. D. (2010) 'An empirical analysis of the gender gap in mathematics', American Economic Journal: Applied Economics, Vol. 2, No. 2, pp. 210-240. https://doi.org/10.1257/app.2.2.210

Jagoda, E. (2008) 'Building the concept of line symmetry', in Maj, B. Pytlak, M. and Swoboda, E. Supporting Independent Thinking Through Mathematical Education, Rzeszów: Wydawnictwo Uniwersytetu Rzeszowskiego, pp. 109-120.

Jirotková, D. (2017) 'Building of schema of geometrical concepts', Proceedings of the 14th International Conference Efficiency and Responsibility in Education (ERIE 2017), Prague, pp. 153-160.

Kaplan, A. and Öztürk, M. (2014) 'Analysis of 2nd-8th Grade Students' Thinking Approaches Toward Understand the Concept of Symmetry', Elementary Education Online, Vol. 13, No. 4, pp. $1502-1515$. 
Kambilombilo, D. and Sakala, W. (2015) 'An Investigation into the Challenges In-Service Student Teachers Encounter in Transformational Geometry, "Reflection and Rotation". The Case of Mufulira College of Education', Journal of Education and Practice, Vol. 6, No. 2, pp. 139-149.

Köse, N. Y. and Özdaş, A. (2009). 'How do the fifth grade primary school students determine the line of symmetry in various geometrical shapes using Cabri Geometry software?', Elementary Education Online, Vol. 8, No. 1, 159-175.

Leikin, R., Berman, A. and Zaslavsky, O. (2000) 'Learning through Teaching: The case of Symmetry', Mathematics Education Research Journal, Vol. 12, No. 1, pp. 18-36. https://doi.org/10.1007/ BF03217072

Lobato, J. and Ellis, A. B. (2002) 'The Focusing Effect of Technology: Implications for Teacher Education', Journal of Technology and Teacher Education, Vol. 10, No. 2, pp. 297-314.

Maaz, K., Trautwein, U., Lüdtke, O. and Baumert, J. (2008) 'Educational transitions and differential learning environments: How explicit between-school tracking contributes to social inequality in educational outcomes', Child Development Perspectives, Vol. 2, No. 2, pp. 99 106. https://doi.org/10.1111/j.1750-8606.2008.00048.x

Martinková, P., Hladká, A. and Potužníková, E. (2020) 'Is academic tracking related to gains in learning competence? Using propensity score matching and differential item change functioning analysis for better understanding of tracking implications', Learning and Instruction, Vol. 66, pp. 1-11. https://doi.org/10.1016/j. learninstruc.2019.101286

Mayberry, J. (1983) 'The Van Hiele Levels of Geometric Thought in Undergraduate Preservice Teachers', Journal for Research in Mathematics Education, Vol. 14, No. 1, pp. 58-69. http://dx.doi. org $/ 10.2307 / 748797$

Ministry of Education, Youth and Sports (2007) Rámcový vzdělávací program pro gymnázia. [Framework Educational Programme for Secondary General Schools]. Prague: VÚP.

Ministry of Education, Youth and Sports (2017). Rámcový vzdělávací program pro základni vzdělávání. [Framework Educational Programme for Basic Education]. Prague: NÚV.

Mirna, M. (2018) 'Errors Analysis of Students in Mathematics Department to Learn Plane Geometry', IOP Conference. Series: Materials Science and Engineering, Vol. 335, No. 1, 012116, pp. 1-4. http://doi. org/10.1088/1757-899X/335/1/012116

Moravcová, V. and Hromadová, J. (2020) 'Straight line or line segment? Students' concepts and their thought processes', Teaching Mathematics and Computer Science, Vol. 18, No. 4, pp. 327-336. http://doi.org/10.5485/TMCS.2020.0497

Moravcová, V., Robová, J., Hromadová, J. and Halas, Z. (2019). 'The development of the concept of axial symmetry in pupils and students', Proceedings of the 16th International Conference on Efficiency and Responsibility in Education (ERIE 2019), Prague, pp. 351-357.

Odvárko, O. and Kadleček, J. (2011) Matematika pro 6. ročník základní školy [3]: Úhel, trojúhelník, osová souměrnost, krychle a kvádr. Prague: Prometheus.

Pont, B., Figueroa, D. T., Zapata, J. and Fraccola, S. (2013) Education Policy Outlook: Czech Republic, Paris: OECD Publishing.

Rendl, M. and Vondrová, N. (2013) Kritická mista matematiky na základní škole očima učitelù, Prague: Charles university.

Rittle-Johnson, B. and Alibali, M. W. (1999) 'Conceptual and procedural knowledge of mathematics: Does one lead to the other?', Journal of Educational Psychology, Vol. 91, No. 1, pp. 175-189. https://doi. org/10.1037/0022-0663.91.1.175
Rittle-Johnson, B. and Schneider, M. (2015) 'Developing conceptual and procedural knowledge of mathematics', in Kadosh, R. C. and Dowker, A. (ed.) The Oxford handbook of numerical cognition, Oxford, UK: Oxford University Press, pp. 1 102-1 118. http://dx.doi.org/10.1093/ oxfordhb/9780199642342.013.014

Rittle-Johnson, B., Siegler, R. S. and Alibali, M. W. (2001) 'Developing conceptual understanding and procedural skill in mathematics: An iterative process', Journal of Educational Psychology, Vol. 93, No. 2, pp. 346-362. https://doi.org/10.1037/0022-0663.93.2.346

Robová, J., Moravcová, V., Halas, Z. and Hromadová, J. (2019) ‘Žákovské koncepty trojúhelníku na začátku druhého stupně vzdělávání', Scientia in educatione, Vol. 10, No. 1, pp. 1-22. https://doi. org/10.14712/18047106.1211

Shulman, L. S. (1986) 'Those Who Understand: Knowledge Growth in Teaching', Educational Researcher, Vol. 15, No. 2, pp. 4-14. https:// doi.org/10.3102/0013189X015002004

Smith, S. E. and Walker, W. J. (1988) 'Sex differences on New York State Regents examinations: Support for the differential course-taking hypothesis', Journal for Research in Mathematics Education, Vol. 19, No. 1, pp. 81-85. https://doi.org/10.2307/749112

Son, J.-W. (2006) 'Investigating preservice teachers' understanding and strategies on a student's errors of reflective symmetry', Proceedings 30th Conference of the International Group for the Psychology of Mathematics Education, Prague: PME, pp. 145-152.

Star, J. R. (2005) 'Reconceptualizing procedural knowledge', Journal for Research in Mathematics Education, Vol. 36, No. 5, pp. 404-411. http://dx.doi.org/10.2307/30034943

Škoda, J. and Doulík, P. (2011) Psychodidaktika, Prague: Grada Publishing.

Tall, D., Gray, E., Bin Ali, M., Crowley, L., DeMarois, P., McGowen, M., Pitta, D., Pinto, M., Thomas, M. and Yusof, Y. (2001) 'Symbols and the bifurcation between procedural and conceptual thinking', Canadian Journal of Science, Mathematics and Technology Education, Vol. 1, No. 1, pp. 81-104. https://doi.org/10.1080/14926150109556452

Thaqi, X., Giménez, J. and Rosich, N. (2011) ‘Geometrical Transformations as Viewed by Prospective Teachers', Proceedings of the Seventh Congress of the European Society for Research in Mathematics Education, Rszeszów: University of Rzeszów, ERME, pp. 578-587.

Tichá, M. (2013) 'Modernizace vyučování matematice v letech 1965-1985', Orbis Scholae, Vol. 7, No. 1, pp. 119-130. https://doi. org/10.14712/23363177.2018.37

Tirosh, D., Tsamir, P., Tabach, M., Levenson, E. and Barkai, R. (2011) 'Geometrical knowledge and geometrical self-efficacy among abused and neglected kindergarten children', Scientia in educatione, Vol. 2, No. 1, pp. 23-36. https://doi.org/10.14712/18047106.52

van Hiele, P. M. (1986) Structure and insight, New York: Academic press.

Vondra, J. (2013) Matematika pro střední školy, 3. dil: Planimetrie, Brno: Didaktis.

Vondrová, N., Rendl, M., Havlíčková, R., Hř́bková, L., Páchová, A. and Žalská, J. (2015) Kritická mista matematiky v řešení žáků, Prague: Karolinum.

Wang, M. and Degol, J. L. (2017) 'Gender Gap in Science, Technology, Engineering, and Mathematics (STEM): Current Knowledge, Implications for Practice, Policy, and Future Directions', Educational Psychology Review, Vol. 29, pp. 119-140. https://doi.org/10.1007/ s10648-015-9355-x

Xistouri, X. and Pitta-Pantazi, D. (2011) 'Elemetary students' Transformational Geometry Abilities and Cognitive Style', Proceedings of the Seventh Congress of the European Society for Research in Mathematics Education, Rszeszów: University of Rzeszów, ERME, pp. 568-577. 